\title{
THE NEW SCIENCE OF PALEOFORESTRY AND ITS LESSONS FOR TO-DAY
}

\author{
By W. R. HadDOW
}

Department of Lands and Forests, Toronto, Ontario.

\begin{abstract}
A CCORDING TO some opinion scientific knowledge is essentially finite; and man, if he lasts long enough, will one day know all there is to know. Moreover, the same opinion holds that in the field of physics and chemistry he is already within measureable distance of the end, which it is predicted he will reach in a surprisingly short time, if the acceleration characteristic of the last half century be maintained. Physics and chemistry having been conquered, biology would be, logically, the next field to be exploited fully - an undertaking which will not soon be accomplished. Then would follow the attack on psychology; and finally it would be possible to "liquidate" sociology-that most complex and difficult of all the sciences. Man, it seems (and especially in the bulk) is his own biggest problem!

Whether or not one agrees with this philosophy it will be admitted that the relative advancement of the sciences and their interdependence is actually as indicated in the presentation. The truth of that is exemplified today in all fields of human activity. Thus, in forestry knowledge of the physical and biological phases is everywhere far advanced relative to knowledge of the sociological (the political, economic and humanitarian) aspects. To this circumstance may be attributed the failure of practical forest management policies, wherever such failure exists. "Technical" knowledge has always been adequate to the needs of forestry. Thus arboriculture was old and successful long before modern forestry was thought of. Forestry fails (if it fails) for want of appropriate social and economic integration.
\end{abstract}

That the advance of social science is dependent on progress in other fields has been admitted; but that it will inevitably follow such progress is an unwarranted assumption which finds no support in history. Social science is backward or archaic whenever it fails to keep up with the times. The present is a time of great activity-and the world is notably in need of a veritable sociology.

Modern forestry, which has very definitely important social implications, was invented in the middle of the eighteenth century as the answer of an intelligent people to a state of necessity-the necessity for greater forest production. Adapted to the political conditions of the times in western Europe, it recognized the institution of the private property and the profit motive; and through the technique of forest regulation, coupled with common knowledge of botany and agriculture, it rendered possible the economic management of forest properties for productive purposes. Thus the investment of a large amount of capital in forestry enterprise was encouraged, and forest owning, managing and working became integrated in society, along with farming and manufacturing enterprise. 
Political philosophy has changed considerably in the last two centuries, with the trend accelerating towards greater social responsibility on the part of Government. Thus while formerly governments were expected to make the rules of the game, they are now being given a hand in it, and are sometimes even found playing solitaire. Democratic people believe that there are often several good ways of doing a job. They are prepared to subordinate personal prejudice, to accept majority opinion, and respect minority views. They encourage the truth, and leave the way open for change.

In the light of present day trends there is something which, for the good of forestry, it is very necessary to keep clearly in view. Reference is made to the fact that the greatest importance of forestry economically, and its principal characteristic, as compared with other economic enterprises, is as a field for the investment of capital. One would judge that this fact is unappreciated in Canada, where the importance of forestry as a field for the employment of labour is often pointed out. Admitting the truth of the latter opinion, a little reflection will make clear that it is in dependent manufacturing in. dustry that the chief employment of labour is to be anticipated. On the other hand, a relatively large investment of capital must be made in the forest itself, if it is to be made productive. It is not enough that such investment should be rendered possible by society. History shows that it must be encouraged as a matter of state policy or business. The reason for that is because forest conservation has wide social benefits which do not accrue to the forest owner, who is therefore restrained by law from having complete freedom with respect to his property; and is in effect required to forego possible selfish advantages of liquidation.

In the course of organic evolution dinosaurs (and countless other creatures) have disappeared from life and are now found only in the rocks, or as fossil specimens gracing the halls of museums, where they serve to edify the young and other curious persons. But the Ginkgo tree, a true relic of the past, persists in nature today, a veritable living fossil. The political scientist who believes in evolution (and who doesn't?) may also have his museum of natural history in which many interesting specimens are displayed. And even as he walks about the world his cunning eye will discover, in his particular jungle, not a few living fossils. Thus in journals recording the acts and proceedings of legislative and executive government he traces the evolution of the constitutional basis of the forest administrations known in Canada to-day. And in the fabric of viable law relating to the forests, as in modern flora, he finds many forms represented whose real affinities are in the past.

The series of legal fossils, bedded in old books, like the natural fossils in geological strata, are not continuous in one place; nor are their mother strata all equally rich in fossil material. Neglecting the superficial and unconsolidated deposits of the immediate past, which according to specialists in several parts of Canada show signs of accelerated evoluntionary impulse, the subjacent strata may be examined. For the most part, throughout post-Confederation time, material of only secondary importance is to be found in the widely scattered localities represented by the several provinces of the Dominion. 
Among a multitude of forms, varying slightly in detail, not a few appear to have become extinct. If a very mixed figure of speech may be permitted, this period may be called appropriately the era of "flowering sawmill plants".

The prime basis of Canadian forest policy stems from a much earlier period, or rather periods; for a conspicuous and most interesting divarication can be traced from the institution under Dalhousie and Maitland-this being a commercial forest policy accompanied by Crown timber dues-a movement of critical importance historically and practically. In the course of time there followed naturally from this fertilization the original Crown Timber Act, whose deviates, like sparrows and starlings, have soared all over the country.

The other principal root of Canadian forest policy was already old when Upper Canada was organized, and for the most part it flourished elsewherenotably in Nova Scotia and New Brunswick. It stems from British colonial administration in the American colonies, whence it actively transported itself in the person of Wentworth, following the revolution. It entered Upper Canada through Wentworth's deputies in Simcoe's time, and persisted there until the general break-up of the system of timber reserves and monopoly contractors.

With the reported plucking in Ontario of the last bloom of pine tree reservations it may be claimed, perhaps, that this line has actually become extinct. Better informed opinion sees in the "forest reserves" policy of comparatively recent date, a significant regeneration of the much earlier policy-an adaptation to suit the times.

Considering the above it is clear that the policy of timber reservation actually long antedates the invention of forestry. Later adaptations of that policy have still failed to graft on it the benefits inherent in forestry science. Under it there still remains to be demonstrated, successful forest management for productive purposes. The policy of exploiting the forests for the benefit of the treasury has, on the whole, been successfully carried out, but at great expense to the forests. It served at first merely towards the support of Imperial authority in the colonies-later to guarantee a civil executive gov. ernment, acceptable alike to the local legislature and to the Crown-allegedly at no expense to the latter. It contributed incidentally in no small way to the violent political upheavals associated with the questions of responsible government, sovereign authority, and control of the revenues of the Crown in the colonies. Subsequently it served increasingly to meet the financial needs of government, and only once or twice has it failed in that respect. Currently this policy shows signs of undergoing a spontaneous metamorphosis. Is a living fossil capable of showing new life? A biologist is inclined to doubt it, but perhaps a more humane philosopher would give a different answer. 